\title{
P11 -La comunidad Celina Ramos: Desmovilización y fundación de un nuevo asentamiento campesino en el bajo Guazapa, municipio de Suchitoto: 1992 - 2016
}

\section{The Celina Ramos community: Demobilization and foundation of a new peassant settlement in the lower Guazapa, municipality of Suchitoto: 1992 - 2016}

\author{
Juan Alberto Flores Bernal*, María Teresa Mosquera \\ Universidad de El Salvador, El Salvador* \\ ${ }^{2}$ Instituto de Estudios Interétnicos-USAC
}

*Autor para correspondencia.

Correo electrónico: juanylahistoria@gmail.com

Resumen

T a finalización de la guerra civil en El Salvador, y la firma de los Acuerdos de Paz el 16 de enero de 1992, dio paso a la creación Ude unidades campesinas y al repartimiento de propiedades agrícolas para beneficiar a desmovilizados de la FAES y FMLN, y tenedores de tierras, o campesinos que habían tomado propiedades agrícolas dentro de las zonas conflictivas. La comunidad Celina Ramos es una de ellas. Al estudiar la experiencia e historia de vida de los habitantes de la comunidad Celina Ramos en el municipio de Suchitoto, al ser beneficiarios del Programa de Transferencia de Tierras, se busca comprender el problema agrario que enfrentaron estas comunidades, durante el proceso de reinserción social familiar y comunitaria de posguerra; en lo referente al tema de la tenencia y usos de las tierras, a la organización productiva, social y política de las comunidades campesinas.

Palabras clave: historia de vidas, toma de tierras, desmovilizados, repatriados, tenedores de tierras, y programa de transferencia de tierras

\section{Abstract}

$\mathrm{T}$ he end of the civil war in El Salvador, and the signing of the Peace Accords on January 16, 1992, gave way to the creation of peasant units and the distribution of agricultural properties to benefit demobilized members of FAES and FMLN, and landholders, or peasants who had taken agricultural property within the conflict zones. The Celina Ramos community is one of them. When studying the experience and life history of the inhabitants of the community Celina Ramos in the municipality of Suchitoto, being beneficiaries of the Land Transfer Program, it seeks to understand the agrarian problem faced by these communities, during the process of family social reintegration and community postwar; in relation to the issue of land tenure and land use, to the productive, social and political organization of peasant communities.

Keywords: history of lives, land grabs, demobilized, repatriated, landholders, and Land Transfer Program 


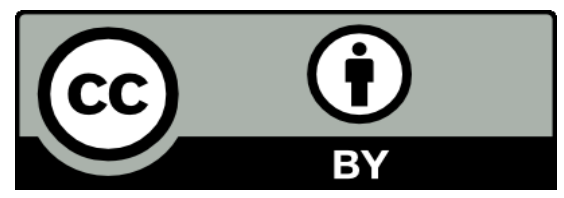

Este texto está protegido por una licencia CreativeCommons 4.0.

Usted es libre para compartir, copiar y redistribuir el material en cualquier medio o formato y adaptar el documento, remezclar, transformar y crear a partir del material para cualquier propósito, incluso comercialmente, siempre que cumpla la condición de atribución: usted debe reconocer el crédito de una obra de manera adecuada, proporcionar un enlace a la licencia, e indicar si se han realizado cambios. Puede hacerlo en cualquier forma razonable, pero no de forma tal que sugiera que tiene el apoyo del licenciante o lo recibe por el uso que hace. 